\title{
Comparison of the effects of lidocaine and fentanyl in epidural anesthesia in dogs
}

\author{
Saritas ZK ${ }^{1}$, Saritas $\mathrm{TB}^{2}$, Pamuk K${ }^{1}$, Korkmaz M${ }^{1}$, Demirkan I ${ }^{1}$, Yaprakci MV ${ }^{1}$, Sivaci RG ${ }^{3}$ \\ Afyon Kocatepe University, Faculty of Veterinary Medicine, Department of Surgery, Afyonkarahisar, Turkey. \\ zksaritas@hotmail.com
}

\begin{abstract}
The study included 12 clinically healthy, adult male dogs of various breeds, admitted to our clinic for castration. After general anesthesia with sevoflurane, we administered epidural fentanyl $(1 \mathrm{mcg} / \mathrm{kg})$ to fentanyl group, while lidocaine group was given Lidocaine $(3 \mathrm{mg} / \mathrm{kg})$ through epidural administration. When hemodynamic parameters were stabilized, first measurements were recorded at minutes $0,15,30,60$ in both groups, which included Heart Rate (HR), body temperature, systolic blood pressure (SBP), diastolic blood pressure (DBP), mean arterial pressure (MAP), sodium $\left(\mathrm{Na}^{+}\right)$, potassium $\left(\mathrm{K}^{+}\right)$, glucose $(\mathrm{GLC})$, and hemoglobin $(\mathrm{HB})$ measurements. In addition, serum samples were obtained from arterial blood at the same measurement times, and $\mathrm{pH}$, $\mathrm{pO}_{2}, \mathrm{pCO}_{2}, \mathrm{HCO}_{3}, \% \mathrm{O}_{2}$ Saturation, BE levels were measured. For hematological analysis, WBC, RBC, HCT, THR counts were performed. For serum biochemical analysis, venous blood samples were collected at minutes 0 and 60 and CK, TP, UREA, ALT, AST, ALB, GGT, CRE, CK-MB parameters were assessed using auto-analyzer. Moreover, cortisol levels were measured in the samples collected at minutes 0,30 , and 60 .

Mean arterial blood pressure values measured at minutes 15, 30 and 60 were found significantly lower in the fentanyl group $(p<0.01)$. In conclusion, we suggest that epidural anesthesia with lidocaine and fentanyl can provide an effective and safe option in high-risk groups (Tab. 5, Fig. 1, Ref. 24). Text in PDF www.elis.sk.

Key words: epidural, dogs, lidocaine, fentanyl.
\end{abstract}

Epidural anesthesia is defined as administration of local anesthetic agents into epidural space in order to eliminate the sense of pain creating non-selective nerve block (1-3). In other words, epidural anesthesia is temporary blockage of axonal transport in the nerve fibers with the injection of local anesthetic drugs into the epidural space. This is achieved by inhibition of spinal nerves within epidural space, the level at which they pierce the dura mater and extend into intervertebral foramina. In epidural anesthesia, larger sensory and sympathetic fibers are blocked, while motor nerve fibers are partially or fully blocked (4).

In comparison with systemic administration, drugs administered in the epidural space are more potent as the drug is localized at the site of action. The duration of analgesia and anesthesia may also be more prolonged, because the drug relies on local blood flow for removal from its binding site and delivery to the systemic circulation, where it is then available for metabolism and excretion (3).

With epidural anesthesia, nerves innervating regions such as pelvis, hind limbs, tail and perineum can be blocked. Epidural anesthesia is considered as a safe alternative to general anesthesia

${ }^{1}$ Afyon Kocatepe University, Faculty of Veterinary Medicine, Depart-
ment of Surgery, Afyonkarahisar, Turkey, ${ }^{2}$ Necmettin Erbakan Univer-
sity, Meram Medical School, Anesthesiology and Reanimation Depart-
ment, Konya, Turkey, and ${ }^{3}$ Afyon Kocatepe University, Medical School,
Anesthesiology and Reanimation Department, Afyonkarahisar, Turkey.

Address for correspondence: Z.K. Saritas, DVM, PhD, Afyon Kocatepe University, Faculty of Veterinary Medicine, Department of Surgery, 03200 Afyonkarahisar, Turkey.

Phone: +90.533 .6198622 , Fax: +90.272 .2281349$ for surgical procedures caudal to the diaphragm that are deemed to be high-risk candidates for general anesthesia $(3,5)$.

Epidurally administered local anesthetics can be used as the sole agent for the intended analgesic or anesthetic effects, without causing any complications. Other drugs such as $\alpha 2$-agonists may be used alone, in combination with a local anesthetic or epidural opioids. However, clinicians think that administration of $\alpha 2$ agonists by the epidural route allows their systemic absorption, which may cause some undesirable effects. Ketamine, non-steroidal antiinflammatory drugs (NSAIDs) and other drugs can be administered epidurally, but these treatments are less effective (6).

The purpose of this study was to compare the effects of epidural administration of fentanyl as narcotic analgesic and Lidocaine $\mathrm{HCl}$ as local anesthetic in sevoflurane-anesthetized dogs, in terms of arterial blood pressure, body temperature, heart rate per minute, certain hematological and biochemical parameters.

\section{Materials and methods}

The research material in this study was 12 clinically healthy, adult male dogs of various breeds, between the ages of 1-5 years, with weights ranging from 12 to $29 \mathrm{~kg}$, which were admitted to our clinic for castration. The dogs were randomly divided into two equal groups. The first group $(n=6)$ received epidurally administered fentanyl (Fentanyl Citrate, Abbot USA). The dogs in the second group $(n=6)$ received epidurally administered lidocaine ( $2 \%$ Vilcain, Vilsan Turkey). Before initiating any research procedures, we obtained a written research ethics committee ap- 
proval by the Local Committee on Animal Research and Ethics of Afyon Kocatepe University (AKU HADYEK) (Reference No: 04.05.2009/32-09). In addition, an informed consent was obtained from each pet owner.

\section{Method}

\section{Anesthesia}

The dogs fasted for 12 hours before the study. The dogs in both groups were administered $0.04 \mathrm{mg} / \mathrm{kg}$ atropine sulfate $(2 \%$ Atropine, Vetas) subcutaneously 45 minutes before the study. The dogs received i.v. midazolam (Dormicum, Roche, Turkey) as premedication in a dosage of $0.3 \mathrm{mg} / \mathrm{kg}$. During the course of the procedure, the dogs in both groups were administered medication and infusion of Ringer's lactate at a dose of $10 \mathrm{ml} / \mathrm{kg}$ per hour through intravenous catheter $(20 \mathrm{G})$ introduced in v. cephalica antebrachii. Induction of anesthesia was conducted by administering $4 \mathrm{mg} / \mathrm{kg}$ dose of propofol (Propofol 1 \% Fresennius Kabi, Germany) via intravenous bolus route. The dogs in both groups were intubated through orotracheal route and attached to the anesthesia machine (Sms 2000 Classic Anesthesia System with Vent-v Automatic Ventilator. SMS, Turkey). Tidal volume was adjusted to $15 \mathrm{ml} / \mathrm{kg}$ and ventilation was 14 times per minute. Maintenance of anesthesia was provided with $1.5 \%$ volume sevoflurane (Sevorane $250 \mathrm{ml}$ Fl. Abbot, USA) in both groups.

Left R. femoralis was prepared under aseptic conditions and the femoral artery (arteria femoralis) was dissected. An arterial catheter (Cavafix) was inserted along arteria femoralis and introduced into the abdominal aorta, connected to a pressure transducer to monitor and record arterial blood pressure on multi-channel monitor (KMA PETAS 800 multi-channel monitor, PETAS Ltd. Turkey). For ECG monitoring, ECG electrodes were attached to all four extremities of the dogs and, ECG tracings from lead II were monitored and recorded on a multi-channel monitor.

\section{Epidural anesthesia procedure}

Once a stable plane of anesthesia was achieved, the dogs to be administered epidural fentanyl and lidocaine were placed in sternal recumbency and the area over the lumbosacral space was shaved and prepared for aseptic procedure. The space between the sixth and seventh lumbar vertebrae and lumbosacral space was identified on the center of the virtual line between the cranial edges of wing of ilium (Ala ossis ilii). The spinosus processes of sacral vertebrae caudal to this space were determined to be shorter, thus preventing misslocation of the area. A spinal needle was then inserted on the midline at an angle of 45 degrees. Before the needle was advanced into the epidural space, the stylet was removed and physiological saline was filled in the hub of the needle. The needle was then advanced and the "pop" was felt as passing through the ligamentum flavum. When the tip of the needle entered into the epidural space, the negative pressure in the space drew the saline into the needle. Suction was applied to confirm correct needle placement by inability to aspirate blood or cerebrospinal fluid. After confirming no aspiration of blood, about $1 \mathrm{ml}$ of air was then injected to ascertain loss of resistance to injection as a further proof of correct needle placement. Visually checking the air bubble in the syringe for compression, the injection was made slowly without any resistance. After the dogs were maintained in a slight head-down tilt position (approximately 200) for $10 \mathrm{~min}$ utes, they were turned in to supine position $(7,8)$.

In the fentanyl group, the dogs received $1 \mathrm{mcg} / \mathrm{kg}$ of fentanyl citrate (Fentanyl Citrate, Abbott USA) combined with $5 \mathrm{ml}$ normal saline, administered into the epidural space through a catheter (for epidural injection, 17 gauge Tuohy needle with a 79.4$\mathrm{mm}$ effective length) and syringe (Double Decker anesthesia tray, Abbott). In the Lidocaine (Vilcain $2 \%$, Vilsan, Turkey) group, once the lumbosacral region was prepared for aseptic injection, the dogs received $3 \mathrm{mg} / \mathrm{kg}$ of $2 \%$ lidocaine $\mathrm{HCl}$ combined with normal saline administered into epidural space through an epidural catheter.

\section{Surgical operation}

Following the epidural anesthesia, castration was performed in both groups with a prescrotal approach.

\section{Biochemical measurements}

Once anesthetized/sedated, epidural administration was conducted in both groups and first measurements, including Heart Rate (HR) per Minute (BPM), body temperature, systolic blood pressure (SBP), diastolic blood pressure (DBP), mean arterial pressure (MAP), were recorded at minutes $0,15,30,60$. Venous blood samples were taken at the same time intervals, and sodium $\left(\mathrm{Na}^{+}\right)$, potassium $\left(\mathrm{K}^{+}\right)$, glucose and hemoglobin levels were measured. For hematological analysis, white blood cell count (WBC), red blood cell count (RBC) and platelets (THR) levels were measured at minutes $0,15,30,60$, using blood count analyzer (Mindray BC2800 Vet CHINA). For serum biochemical analysis, venous blood samples were collected at minutes 0 and 60 and urea, creatinine kinase (CK), total protein (TP), alanine aminotransferase (ALT), aspartateaminotransferase (AST), albumin (ALB), gamma- lutamyltransferase (GGT), creatinine (CRE), and creatine kinasemyocardial band (CK-MB) parameters were measured using an auto-analyzer (Cobes C 111, Roche, Germany).

After the induction of general anesthesia, arterial blood gas analysis was performed on arterial blood specimens withdrawn from the body at minutes $0,15,30,60$ (Gastat mini JAPAN).

In addition, blood samples for cortisol evaluation were taken at minutes 0,30, 60 and the quantitative analysis of cortisol levels was done using ELISA method. Administration of sevoflurane was discontinued after 60 minutes and the animals were allowed to awaken.

\section{Statistical analysis}

The results of measurements conducted on blood samples obtained at minutes $0,15,30,60$ were analyzed on the Statistical Package for the Social Sciences (SPSS for Windows), using Student's t-test for paired samples and ANOVA for repeated measures. The measurement results in both groups were assessed as Average (Mean) \pm Standard Deviation (SD). $\mathrm{p}<0.05$ was considered statistically significant. 
Tab. 1. Some Vital Parameters Results in Fentanyl $(n=6)$ and Lidocaine $(n=6)$ Groups.

\begin{tabular}{|c|c|c|c|c|c|}
\hline Time/Groups & $\begin{array}{l}\text { Heart Rate } \\
\text { (HR) } \\
\text { Beat/min. }\end{array}$ & $\begin{array}{c}\text { Rectal } \\
\text { Temperature } \\
(\mathrm{Co})\end{array}$ & $\begin{array}{c}\text { Systolic Arterial } \\
\text { Pressure (SAP) } \\
(\mathrm{mmHg})\end{array}$ & $\begin{array}{c}\text { Diastolic Arterial } \\
\text { Pressure (DAP) } \\
(\mathrm{mmHg})\end{array}$ & $\begin{array}{c}\text { Mean Arterial } \\
\text { Pressure (MAP) } \\
(\mathrm{mmHg})\end{array}$ \\
\hline \multicolumn{6}{|l|}{$0 . \min$} \\
\hline Fentanyl & $109 \pm 18$ & $38.7 \pm 0.3^{\mathrm{a}}$ & $111 \pm 7^{\mathrm{abc}}$ & $75 \pm 7^{\mathrm{abc}}$ & $90 \pm 9^{\mathrm{ab}}$ \\
\hline Lidocaine & $113 \pm 12$ & $38.4 \pm 0.4^{\mathrm{ab}}$ & $117 \pm 11^{\mathrm{ab}}$ & $84 \pm 13^{\mathrm{abc}}$ & $92 \pm 7^{\mathrm{ab}}$ \\
\hline \multicolumn{6}{|l|}{$15 . \mathrm{min}$} \\
\hline Fentanil & $95 \pm 19$ & $38.7 \pm 0.3^{\mathrm{a}}$ & $95 \pm 4^{\mathrm{bc}}$ & $66 \pm 8^{b c}$ & $71 \pm 5^{\mathrm{b}}$ \\
\hline Lidocaine & $112 \pm 14$ & $38.3 \pm 0.4^{\mathrm{ab}}$ & $98 \pm 10^{\mathrm{abc}}$ & $73 \pm 10^{\mathrm{abc}}$ & $77 \pm 11^{\mathrm{ab}}$ \\
\hline \multicolumn{6}{|l|}{$30 . \min$} \\
\hline Fentanyl & $95 \pm 15$ & $38.6 \pm 0.3^{\mathrm{ab}}$ & $91 \pm 1^{\mathrm{c}}$ & $63 \pm^{c}$ & $74 \pm 3^{b}$ \\
\hline Lidocaine & $113 \pm 15$ & $38.02 \pm 0.4^{\mathrm{a}}$ & $119 \pm 19^{a}$ & $88 \pm 18^{a}$ & $96 \pm 18^{a}$ \\
\hline \multicolumn{6}{|l|}{$60 . \mathrm{min}$} \\
\hline Fentanyl & $91 \pm 15$ & $38.5 \pm 0.1^{\mathrm{ab}}$ & $105 \pm 14^{\mathrm{abc}}$ & $65 \pm 6^{\mathrm{bc}}$ & $79 \pm 7^{\mathrm{ab}}$ \\
\hline Lidocain & $110 \pm 17$ & $37.9 \pm 0.4^{\mathrm{b}}$ & $120 \pm 23^{a}$ & $86 \pm 19^{a b}$ & $98 \pm 20^{\mathrm{a}}$ \\
\hline $\mathrm{P}$ & 0.065 & $0.002 *$ & $0.001 *$ & $0.001^{*}$ & $0.001 *$ \\
\hline
\end{tabular}

a.b.c Values in the same column with different letters are statistically significant.

$*(\mathrm{p}<0.01)$.

Tab. 2. Some Biochemical results in Fentanyl $(n=6)$ and Lidocaine (n=6) Groups.

\begin{tabular}{lcccc}
\hline Time/Groups & $\begin{array}{c}\mathrm{Na}^{+} \\
(\mathrm{mmol} / \mathrm{L})\end{array}$ & $\begin{array}{c}\mathrm{K}^{+} \\
(\mathrm{mmol} / \mathrm{L})\end{array}$ & $\begin{array}{c}\text { Glucose } \\
(\mathrm{mg} / \mathrm{dl})\end{array}$ & $\begin{array}{c}\mathrm{HB} \\
(\mathrm{g} / \mathrm{dL})\end{array}$ \\
\hline 0.min & & & \\
Fentanyl & $147,1 \pm 4,6$ & $4,31 \pm 0,44$ & $69 \pm 12^{\mathrm{ab}}$ & $10,1 \pm 2,2$ \\
Lidocaine & $149,3 \pm 6,5$ & $5,05 \pm 0,52$ & $74 \pm 15^{\mathrm{ab}}$ & $11,4 \pm 2,5$ \\
\hline 15. min & & & \\
Fentanyl & $147,1 \pm 2,1$ & $5,3 \pm 1,2$ & $65 \pm 15^{\mathrm{b}}$ & $9,4 \pm 1$ \\
Lidocaine & $150,9 \pm 4,9$ & $4,95 \pm 0,7$ & $76 \pm 15^{\mathrm{ab}}$ & $11,2 \pm 2,5$ \\
\hline 30.min & & & \\
Fentanyl & $145,1 \pm 2,1$ & $4,13 \pm 0,4$ & $61 \pm 16^{\mathrm{b}}$ & $10,8 \pm 2,4$ \\
Lidocaine & $151,9 \pm 2,3$ & $5,1 \pm 0,41$ & $99 \pm 33^{\mathrm{a}}$ & $11 \pm 3$ \\
\hline 60.min & & & \\
Fentanyl & $146,1 \pm 4,1$ & $4,56 \pm 0,87$ & $52 \pm 13^{\mathrm{b}}$ & $11,2 \pm 2,9$ \\
Lidocaine & $153,3 \pm 10,7$ & $4,98 \pm 0,5$ & $77 \pm 10^{\text {ab }}$ & $11,4 \pm 3$ \\
\hline P: & 0,116 & 0,59 & $0,003^{* *}$ & 0,846 \\
\hline a,b Values in the same column with different letters are statistically significant.
\end{tabular}

Tab. 3. Some Hematologic Results in Fentanyl $(n=6)$ and Lidocaine $(n=6)$ Groups.

\begin{tabular}{lcccc}
\hline Time/Groups & $\begin{array}{c}\mathrm{WBC} \\
\left(\mathrm{m} / \mathrm{mm}^{3}\right)\end{array}$ & $\begin{array}{c}\mathrm{RBC} \\
\left(\mathrm{m} / \mathrm{mm}^{3}\right)\end{array}$ & $\begin{array}{c}\text { HCT } \\
(\%)\end{array}$ & $\begin{array}{c}\text { THR } \\
\left(\mathrm{m} / \mathrm{mm}^{3}\right)\end{array}$ \\
\hline 0.min & & & & \\
Fentanil & $11.96 \pm 2.39$ & $5.19 \pm 1.51$ & $30.58 \pm 7.9^{\mathrm{ab}}$ & $467 \pm 198$ \\
Lidocaine & $10.87 \pm 3.63$ & $6.5 \pm 1.81$ & $38.3 \pm 10.5^{\mathrm{a}}$ & $460 \pm 94$ \\
\hline 60.min & & & & \\
Fentanyl & $11.07 \pm 2.78$ & $5.18 \pm 1.99$ & $28.16 \pm 9.02^{\mathrm{ab}}$ & $369 \pm 117$ \\
Lidocaine & $9.87 \pm 2.05$ & $4.57 \pm 1.29$ & $22.41 \pm 7.87^{\mathrm{b}}$ & $348 \pm 55$ \\
\hline P & 0.639 & 0.270 & 0.043 & 0.274 \\
\hline
\end{tabular}

a,b Values in the same column with different letters are statistically significant.

\section{Results}

In both groups of fentanyl and lidocaine, HR per Minute (BPM) measurements were performed at minutes $0,15,30$ and 60 . The findings recorded at repeated measurements in fentanyl and Lidocaine groups were as follows: $109 \pm 18$ and $113 \pm 12$ beats/ min, $95 \pm 19$ and $112 \pm 14$ beats/min, $95 \pm 15$ and $113 \pm 15$ beats/ min and $91 \pm 15$ and $110 \pm 17$ beats/min, respectively. For this parameter, there was no statistically significant difference between the measurement times ( $p>0.05)$ (Tab. 1).

In the measurement of body temperature, lidocaine group showed a statistically significant decrease at the 60th minute (fentanyl: $38.5 \pm 0.1$ and Lidocaine: $37.9 \pm 0.4 \mathrm{C} 0)(\mathrm{p}<0.01)($ Tab. 1$)$.

Mean arterial blood pressure values were significantly lower in the fentanyl group at 15, 30 and 60 minutes $(\mathrm{p}<0.01)$ (Tab. 1). There was a statistically significant decrease in systolic and diastolic blood pressure values of fentanyl group at 15,30 and 60 minutes $(\mathrm{p}<0.001)$ (Tab. 1).

$\mathrm{Na}^{+}, \mathrm{K}^{+}$, and hemoglobin ( $\mathrm{Hb}$ ) levels did not change significantly in both groups. On the other hand, lidocaine group showed a statistically significant increase in the blood glucose level at 30 minutes $(\mathrm{p}<0.01)$. However, this increase was within the reference range (Tab. 2).

For hematological analysis, measurements were taken at 0 and 60 minutes, the results are shown in Table 3. The results showed no significant difference between the groups in terms of WBC, RBC, THR. However, hematocrit (HCT) levels significantly decreased

Tab. 4. Some Biochemical Prameters in Fentanyl $(n=6)$ and Lidocaine $(n=6)$ Groups.

\begin{tabular}{|c|c|c|c|c|c|c|c|c|c|}
\hline Time/Groups & $\begin{array}{c}\mathrm{CK} \\
(\mathrm{IU} / \mathrm{L})\end{array}$ & $\begin{array}{c}\mathrm{TP} \\
(\mathrm{g} / \mathrm{dL})\end{array}$ & $\begin{array}{c}\text { UREA } \\
(\mathrm{mg} / \mathrm{dL})\end{array}$ & $\begin{array}{c}\text { ALT } \\
(\mathrm{IU} / \mathrm{L})\end{array}$ & $\begin{array}{c}\mathrm{AST} \\
(\mathrm{IU} / \mathrm{dL})\end{array}$ & $\begin{array}{c}\text { ALB } \\
(\mathrm{g} / \mathrm{dL})\end{array}$ & $\begin{array}{c}\text { GGT } \\
\text { (IU/dL) }\end{array}$ & $\begin{array}{c}\text { CRE } \\
(\mathrm{mg} / \mathrm{dL})\end{array}$ & $\begin{array}{l}\text { CK-MB } \\
(\mathrm{IU} / \mathrm{dL})\end{array}$ \\
\hline \multicolumn{10}{|l|}{$0 \mathrm{~min}}$. \\
\hline Fentanyl & $357 \pm 52$ & $5.6 \pm 0.3$ & $15.6 \pm 1.7$ & $36 \pm 3.2$ & $43.8 \pm 5.2$ & $2.71 \pm 0.13$ & $2.66 \pm 0.5$ & $0.61 \pm 0.09$ & $407 \pm 45$ \\
\hline Lidocaine & $127 \pm 10$ & $6.5 \pm 0.2$ & $18 \pm 2$ & $32.8 \pm 3.2$ & $27.8 \pm 3.8$ & $3.21 \pm 0.23$ & $2.16 \pm 0.47$ & $0.76 \pm 0.1$ & $266 \pm 23$ \\
\hline \multicolumn{10}{|l|}{$60 \mathrm{~min}}$. \\
\hline Fentanyl & $188 \pm 32$ & $4.9 \pm 0.2 *$ & $18 \pm 2$ & $30 \pm 3$ & $31 \pm 2 *$ & $2.38 \pm 0.1^{*}$ & $2.33 \pm 0.6$ & $0.61 \pm 0.09$ & $225 \pm 44$ \\
\hline Lidocaine & $71 \pm 3$ & $5.6 \pm 0.1$ & $18.3 \pm 2$ & $27.6 \pm 2.1$ & $20.6 \pm 3.4$ & $2.78 \pm 0.2$ & $1.83 \pm 0.47$ & $0.78 \pm 0.1$ & $126 \pm 8^{*}$ \\
\hline$\overline{\mathrm{P}}$ & 0.000 & 0.001 & 0.6 & 0.2 & 0.003 & 0.02 & 0.7 & 0.44 & 0.000 \\
\hline
\end{tabular}


Tab. 5. Arterial Blood Gases Analysis Results in Fentanyl $(n=6)$ and Lidocaine $(n=6)$ Groups.

\begin{tabular}{|c|c|c|c|c|c|c|}
\hline Time/Groups & $\begin{array}{c}\mathrm{pH} \\
\left(-\log _{10}\left[\mathrm{H}^{+}\right]\right. \\
\end{array}$ & $\begin{array}{c}\mathrm{pCO}_{2} \\
(\mathrm{mmHg}) \\
\end{array}$ & $\begin{array}{c}\mathrm{pO}_{2} \\
(\mathrm{mmHg}) \\
\end{array}$ & $\begin{array}{c}\mathrm{HCO}_{3} \\
(\mathrm{mmol} / \mathrm{L}) \\
\end{array}$ & $\begin{array}{c}\mathrm{O}_{2} \mathrm{SAT} \\
(\%) \\
\end{array}$ & $\begin{array}{c}\mathrm{BE} \\
(\mathrm{mmol} / \mathrm{L}) \\
\end{array}$ \\
\hline \multicolumn{7}{|l|}{$0 . \min$} \\
\hline Fentanyl & $7.346 \pm 0.02$ & $39.6 \pm 5.9$ & $511 \pm 72^{\mathrm{a}}$ & $23.16 \pm 3.3^{\mathrm{a}}$ & $99.55 \pm 0.76^{\mathrm{a}}$ & $-2.15 \pm 1.48^{\mathrm{a}}$ \\
\hline Lidocaine & $7.258 \pm 0.02$ & $34.6 \pm 9$ & $381 \pm 22^{c}$ & $15.4 \pm 3.2^{\mathrm{b}}$ & $98.80 \pm 0.73^{\mathrm{abc}}$ & $-10.43 \pm 0.61^{\mathrm{ab}}$ \\
\hline \multicolumn{7}{|l|}{$15 . \mathrm{min}$} \\
\hline Fentanyl & $7.34 \pm 0.02$ & $34.7 \pm 8$ & $494 \pm 89^{\mathrm{ab}}$ & $19.98 \pm 5.8^{\mathrm{ab}}$ & $99.15 \pm 0.53^{\mathrm{ab}}$ & $-4.73 \pm 3.07^{\mathrm{ab}}$ \\
\hline Lidocaine & $7.266 \pm 0.02$ & $30.8 \pm 4.4$ & $403 \pm 95^{\mathrm{bc}}$ & $14.01 \pm 0.97^{\mathrm{b}}$ & $97.90 \pm 1.01^{\mathrm{bc}}$ & $-11.35 \pm 6.62^{b}$ \\
\hline \multicolumn{7}{|l|}{$30 . \mathrm{min}$} \\
\hline Fentanyl & $7.36 \pm 0.1$ & $31.5 \pm 8.2$ & $382 \pm 137^{\mathrm{c}}$ & $18.70 \pm 5.7^{\mathrm{ab}}$ & $98.90 \pm 0.85^{\mathrm{abc}}$ & $-4.90 \pm 1.59^{\mathrm{ab}}$ \\
\hline Lidocain & $7.266 \pm 0.02$ & $81 \pm 108$ & $400 \pm 26^{\mathrm{bc}}$ & $16.3 \pm 1.9^{\mathrm{ab}}$ & $97.90 \pm 1.13^{\mathrm{bc}}$ & $-9.45 \pm 6.96^{\mathrm{ab}}$ \\
\hline \multicolumn{7}{|l|}{$60 . \mathrm{min}$} \\
\hline Fentanyl & $7.345 \pm 0.02$ & $30.7 \pm 7.2$ & $410 \pm 66^{\mathrm{bc}}$ & $17.53 \pm 5.97^{\mathrm{ab}}$ & $99.46 \pm 0.56^{\mathrm{a}}$ & $-6.73 \pm 1.81^{a b}$ \\
\hline Lidocaine & $7.276 \pm 0.04$ & $30.3 \pm 4.2$ & $440 \pm 51^{\mathrm{abc}}$ & $14.26 \pm 1.53^{\mathrm{b}}$ & $97.50 \pm 0.83^{\mathrm{c}}$ & $-10.88 \pm 1.52^{b}$ \\
\hline $\mathrm{P}$ & 0.085 & 0.341 & $0.036^{*}$ & $0.005 * *$ & $0.0001 * * *$ & $0.008 * *$ \\
\hline
\end{tabular}

a,b,c Values in the same column with different letters are statistically significant.

in lidocaine group at minute $60(28.16 \pm 9.02$ and $22.41 \pm 7.87$, respectively) $(\mathrm{p}<0.05)$ (Tab. 3).

For biochemical analyses, urea, CK, TP, ALT, AST levels were measured at minutes 0 and 60 (Tab. 4). CK values for the fentanyl and lidocaine groups recorded at the given measurement times were as follows: $357 \pm 52$ and $127 \pm 10,188 \pm 32$ and 71 \pm 3 , respectively. The decrease at the 60 th minute in lidocaine group was found statistically significant $(\mathrm{p}<0.001)$. TP values for fentanyl and Lidocaine groups were recorded as $5.6 \pm 0.3$ and $6.5 \pm 0.2,4.9 \pm 0.2$ and $5.6 \pm 0.1$, respectively. The decrease at the 60 th minute in lidocaine group was found statistically significant $(p<0.001)$. AST values for fentanyl and Lidocaine groups were recorded as $43.8 \pm 5.2$ and $27.8 \pm 3.8,31 \pm 2$ and $20.6 \pm 3.4$, respectively. The difference at 60 th minute between the two groups was found statistically significant $(\mathrm{p}<0.001)$. CK-MB values for fentanyl and Lidocaine groups recorded at the given times were as follows: $407 \pm 45$ and $266 \pm 23,225 \pm 44$ and $126 \pm 8$, respectively. The decrease at the 60th minute in Lidocaine group was found statistically significant ( $<<0.0001)$ (Tab. 4).

Arterial blood gas analysis performed on arterial blood specimens showed no significant difference in $\mathrm{pH}$ and $\mathrm{pCO}_{2}$ values.

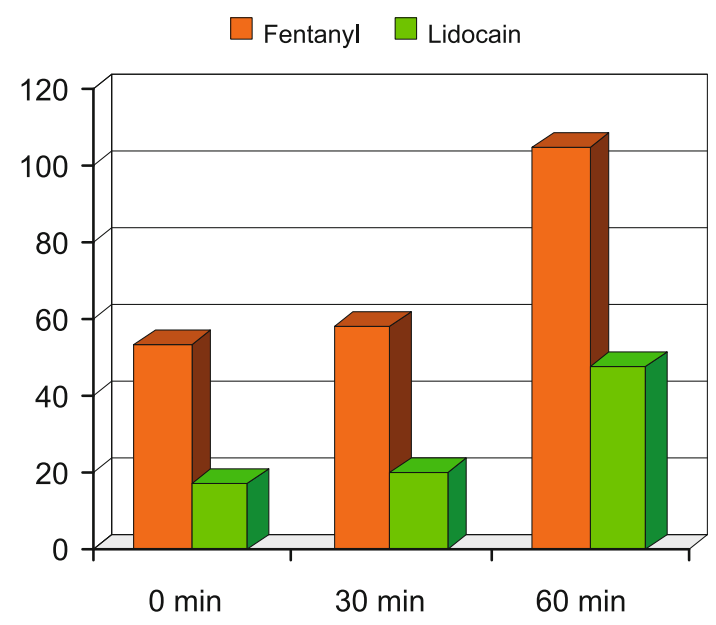

Fig. 1. Cortisol levels in Fentanyl and Lidocaine groups.
However, metabolic acidosis was observed in lidocaine group, the acidosis was corrected after measurements. Accordingly, $\mathrm{HCO}_{3}$ levels showed statistically significant decrease in fentanyl group after 15,30 , and 60 minutes compared with minute $0\left(\mathrm{HCO}_{3}\right.$ levels of fentanyl and lidocaine group at 0 and 60 minutes: $23.16 \pm$ 3.3 and $15.4 \pm 3.2 \mathrm{mmol} / 1,17.53 \pm 5.97$ and $14.26 \pm 1.53 \mathrm{mmol} / \mathrm{l}$, respectively) ( $\mathrm{p}<0.01)$. In parallel with this, BE levels increased in fentanyl group (Tab. 5).

In both groups, cortisol levels were measured at minutes 0,30 , and 60 , however, no significant difference was found between the cortisol levels of groups. However, the increase in fentanyl group was at a mathematically higher level (Fig. 1).

\section{Discussion}

In our study, we aimed to compare the effects of epidurally administered fentanyl and lidocaine on hemodynamic parameters and certain hematological and biochemical parameters in sevoflurane-anesthetized dogs.

In dogs, the lumbosacral intervertebral (LS) space is the preferred injection site for epidural anesthesia $(3,5,6,9,10)$, while in larger dogs, the sacrococcygeal space is sometimes preferred for epidural injection $(5,6)$. In some cases, precise identification of intervertebral space may be difficult or epidural needle may not be placed into the epidural space. This is a common issue as the location of epidural space is rather difficult in animals with large amount of epidural fat (5). In this study, we used dogs with an average weight of $20 \mathrm{~kg}$, which allowed epidural injections to be administered into LS space. We encountered no difficulties in the placement of Tuohy needle into the epidural space.

It has been reported that dogs might develop a variety of complications after the administration of epidural anesthesia $(1,6,11$, 12). Iff and Moens (12) reported that two dogs developed hypotension, and bradycardia after extradural injections of lidocaine/ bupivacaine or lidocaine/bupivacaine/morphine. Savvas (13) reported that cardiac arrest occurred in a dog following an epidural injection of lidocaine. In our study, we observed decreases in blood pressure values after the epidural injection of lidocaine, which was consistent with the relevant literature, but no bradycardia or 
cardiac arrest occurred in any of the cases. It was considered that the reason why bradycardia did not occur in any of the groups was that we did not administer excessive amounts of local anesthetic, which prevented the occurrence of sympathetic blockade, and we did not administer injection into the epidural veins.

Naganobu et al (14) reported that epidural administration of morphine and fentanyl in dogs anesthetized with sevoflurane induced statistically significant decreases in diastolic and mean arterial blood pressure values. A study conducted by Sakonju (15) investigated the effects of continuous epidural administration of lidocaine $(3 \mathrm{mg} / \mathrm{kg})$ in dogs anesthetized with isoflurane and they found that HR and MAP significantly decreased immediately after epidural administration of lidocaine. Vnuk et al (16) showed that epidural administration of lidocaine $(4 \mathrm{mg} / \mathrm{kg})$ in dogs under isoflurane anesthesia had no significant changes on HR and MAP. In the present study, we observed declines in cardiovascular parameters following the administration of epidural anesthesia. In both groups, the decrease in HR was not statistically significant, however, the observed decrease in the arterial blood pressure values was found to be statistically significant. Reductions in the blood pressure were thought to result from the sympathetic blockade caused by epidurally administered drugs.

A literature search revealed no studies evaluating the effects of epidurally administered fentanyl and lidocaine on hemodynamic parameters and certain hematological and biochemical parameters in sevoflurane-anesthetized dogs. However, there are some studies evaluating the effects of general anesthetic agents on biochemical parameters $(17,18)$. Apaydin and Koc (17) reported that there were no statistical differences in AST, CK, urea and CRE parameters in dogs under isoflurane and sevoflurane anesthesia, whereas serum ALT levels at minutes 60 and 120 were detected to be statistically different between the two groups. In the same study. Apaydin and Koc (17) also demonstrated that isoflurane and sevoflurane anesthesia did not cause any significant differences in $\mathrm{Na}^{+}$and $\mathrm{K}^{+}$levels. (18), in their study where they examined the effects of medetomidine-ketamine-atipamezole anaesthesia protocol on dogs, reported that the differences in ALT, AST, BUN and CK measurements at different times were statistically significant. Korkmaz and Saritas (8) reported that epidural administration of bupivacaine and levobupivacain in dogs did not cause any significant changes in blood biochemistry parameters. The study by Yuan et al (19), which investigated the changes in serum enzymes considered as biochemical indicators of hepatobiliary function in dogs following anaesthesia with isoflurane and sevoflurane, reported that there were significant increases at 24 hours post-anesthesia in some parameters, but they returned to normal levels over time. In our study, changes with time in CK, AST and CK-MB levels were found to be significant. However, these changes were still within normal physiological limits.

Simeneova (20) reported that epidural administration of lidocaine after sedation with acepromazine in dogs did not cause a significant change in blood gas parameters. It was reported that epidural administration of morphine and fentanyl in dogs anesthetized with sevoflurane induced a significant increase in $\mathrm{paCO}_{2}$ level, whereas arterial $\mathrm{pH}$ and base excess were significantly de- creased (14). A research demonstrated that the epidural administration of lidocaine alone and lidocaine and fentanyl in dogs does not produce any significant changes in $\mathrm{paCO}_{2}$ levels (21). Another study by Aminkov and Hubenov (22) reported that the mixture of lidocaine and morphine introduced epidurally in dogs anesthetized with halothane improved analgesia and simultaneously minimized the respiratory side effects. In our study, the sevoflurane-anesthetized dogs received epidurally administered fentanyl or lidocaine. In both groups, there was no significant change in the levels of $\mathrm{pH}$ and $\mathrm{paCO}_{2}$, while the changes in time in the values of $\mathrm{paO}_{2}, \mathrm{HCO}_{3}$ and Base Excess (BE) were found to be statistically significant.

Serum cortisol levels of both groups were measured at minutes 0,30 , and 60 before the administration of epidural anesthesia. Perez et al (23) investigated the effects of intratesticular injection of bupivacaine and epidural administration of morphine in dogs undergoing castration in their study, reported that dogs in the intratesticular bupivacaine group had serum cortisol levels significantly lower than the other two groups. In our study, serum cortisol levels were elevated in both groups, but they were lower in the lidocaine group. Although statistically insignificant, the increase in fentanyl group at 60th minute was concluded to be resulting from the reduction in the effect of fentanyl.

Epidural anesthesia appears to be a preferable alternative to general anesthesia for older dogs and high-risk cases where general anesthesia is not indicated. In their study conducted on dogs, Rauser et al (24) indicated that epidural administration of lidocaine, fentanyl or combination of both reduced the dose of general anesthetics, which is important in the management of critically ill patients. In the current study, we found that epidural administration of fentanyl or lidocaine did not cause a significant change in HR, arterial blood pressure, hematological and biochemical parameters. Considering this fact, our study, which examined the applicability of epidurally administered local anesthetics and narcotic analgesics, determined that fentanyl decreased arterial blood pressure more than lidocaine did, in contrast to the data provided in the relevant literature.

\section{Conclusion}

In high-risk groups, administration of opioids and local anesthetics for epidural anesthesia and intra- and postoperative analgesia may be a preferable alternative. We also concluded that this approach could reduce the dose of general anesthetics, thus minimizing the side effects of anesthesia. However, further studies that will evaluate the effects of epidural administration of fentanyl and lidocaine in awake or sedated dogs are needed to confirm these results.

\section{References}

1. Skarda R. Local and regional analgesia. Principles and practice of veterinary anesthesia Los Angeles, Williams \& Wilkins: 1987, 91-134.

2. Skarda RT, Tranquilli WJ. Local and regional anesthetic and analgesic techniques: dogs. Williams \& Wilkins; 1996, 426-447. 
3. Torske KE, Dyson DH. Epidural analgesia and anesthesia. Veter Clin North Amer: Small Animal Practice 2000; 30 (4): 859-874.

4. Collins VJ. Principles of anesthesiology. Amer J Med Sci 1967; 253 (3): 380 .

5. Jones RS. Epidural analgesia in the dog and cat. Veter J 2001; 161 (2): 123-131.

6. Valverde A. Epidural analgesia and anesthesia in dogs and cats. Veter Clin North Amer: Small Animal Practice 2008; 38 (6): 1205-1230.

7. Pekcan Z, Koc B. The post-operative analgesic effects of epidurally administered morphine and transdermal fentanyl patch after ovariohysterectomy in dogs. Vet Anaesth Analg 2010; 37 (6): 557-565.

8. Korkmaz M, Saritas ZK. Comparison of the Effects of Epidurally Administered Bupivacaine and Levobupivacaine in Conscious Dogs. Acta Sci Veter 2013; 41: 1132.

9. Otero P. Epidural anaesthesia and analgesia. 199-201. Prague: Czech Small Animal Veterinary Association; 2006.

10. Robertson SA. How to perform epidural injections in dogs and cats. 72-73. Gainesville: Eastern States Veterinary Association; 2005.

11. Herperger LJ. Postoperative urinary retention in a dog following morphine with bupivacaine epidural analgesia. Canad Veter J 1998; 39 (10): 650 .

12. Iff I, Moens Y. Two cases of bradyarrhythmia and hypotension after extradural injections in dogs. Vet Anaesth Analg 2008; 35 (3): 265-269.

13. Savvas I, Anagnostou T, Papazoglou LG, Raptopoulos D. Successful resuscitation from cardiac arrest associated with extradural lidocaine in a dog. Vet Anaesth Analg 2006; 33 (3): 175-178.

14. Naganobu K, Maeda N, Miyamoto T, Hagio M, Nakamura T, Takasaki M. Cardiorespiratory effects of epidural administration of morphine and fentanyl in dogs anesthetized with sevoflurane. J Amer Veter Med Ass 2004; 224 (1): 67-70.
15. Sakonju I, Maeda K, Karasawa K, Tadokoro T, Kakuta T, Takase K. Plasma concentration and cardiovascular effects of lidocaine during continuous epidural administration in dogs anesthetized with isoflurane. J Veter Med Sci /the Japanese Society of Veterinary Science 2011; 73 (3): 393-398.

16. Vnuk D, Lemo N, Radisic B, Nesek-Adam V, Musulin A, Kos J. Serum lidocaine concentration after epidural administration in dogs. Veter Med (Praha) 2006; 51 (8): 432.

17. Apaydin N, Koc B. Köpeklerde Isoflurane ve Sevoflurane Anestezisinin Hemodinamik ve Biyokimyasal Parametrelere Olan Etkilerinin Karşilaştirilmasi. Veteriner Cerrahi Dergisi 2005; 11: 31-35.

18. Günay C, Sagliyan A, Balikci E, Unsaldi E. Comparison of intravenous bolus vs. intravenous infusion as mode of administration of ketamine HCl-midazolam in dogs. Veteriner Cerrahi Dergisi 2004; 10 (3/4): 5-10.

19. Yuan Z, Liu J, Liang X, Lin D. Serum biochemical indicators of hepatobiliary function in dogs following prolonged anaesthesia with sevoflurane or isoflurane. Vet Anaesth Analg 2012; 39 (3): 296-300.

20. Simeonova G. Acid-base status and blood gas analysis in three different anaesthesia schemes in dogs. Turk J Veter Anim Sci 2004; 28: 769-774.

21. Aminkov B. Comparison between lidocaine alone and fentanyl with lidocaine for epidural anaesthesia in dogs. Rev Méd Vétér;147, 1996.

22. Aminkov B, Hubenov H. Cardiovascular and respiratory effects of epidural lidocaine and morphine administered in dogs anaesthetized with halothane. Rev Méd Vétér 2001; 152 (1): 71-76.

23. Perez TE, Grubb TL, Greene SA, Meyer S, Valdez N, Bingman J et al. Effects of intratesticular injection of bupivacaine and epidural administration of morphine in dogs undergoing castration. J Amer Veter Med Ass 2013; 242 (5): 631-642.

24. Rauser P, Lexmaulova L, Vlasin M, Fichtel T, Lorenzova J. Effect of epidural administration of lidocaine, fentanyl and their combination on the minimum alveolar concentration of halothane in dogs. Veter Med 2004; 49 (11): 421-426. 